\title{
AT THE INTERSECTION OF RISK When literary journalism and sociology study urban problems by means of akin methodologies
}

\section{Isabel Soares}

Instituto Superior de Ciências Sociais e Políticas, CAPP, Universidade de Lisboa, Lisboa, Portugal

\begin{abstract}
Literary journalism, or long form reporting, intersects sociological research at the methodological level when analysing urban problems. To establish the connection between literary journalism and sociology, we focus on the influence early literary journalists had on the sociological/imagological and narrative construction of social problems and how literary journalism continues to be a tool in the unveiling of risk-related issues such as the exploitation of cheap labour and the degradation of urban environments. We examine a corpus of literary journalism texts through qualitative methods, namely content and discourse analysis, to conclude that literary journalism and sociology resort to the same data gathering methodologies, interviews, surveys and statistics, while narratively exposing life at the socioeconomic peripheries.
\end{abstract}

Keywords: literary journalism, sociology, urban problems, sociological methodologies.

Resumo O jornalismo literário, alojado na reportagem e na crónica, intersecciona a pesquisa sociológica ao nível metodológico quando analisa os problemas urbanos. A fim de estabelecer um elo entre o jornalismo literário e a sociologia, focamo-nos na influência que os primeiros jornalistas literários tiveram na construção narrativa, sociológica e imagética dos problemas sociais e como aquele continua a ser instrumental para a revelação de problemas associados ao risco, como a exploração de trabalho não qualificado ou a degradação do espaço urbano. Examinamos um corpus de textos jornalístico-literários através de métodos qualitativos, nomeadamente análise de discurso e de conteúdo, para concluir que o jornalismo literário e a sociologia recorrem às mesmas metodologias de recolha de dados, entrevistas, inquéritos, estatísticas, com o fito de exporem as condições de vida nas periferias socioeconómicas.

Palavras-chave: jornalismo literário, sociologia, problemas urbanos, metodologias sociológicas.

Résumé Le journalisme littéraire, où se classent le reportage et la chronique, emprunte sa méthodologie à la recherche sociologique lorsqu'il analyse les problèmes urbains. Afin d'établir un lien entre le journalisme littéraire et la sociologie, nous nous sommes centrés sur l'influence qu'ont eue les premiers journalistes littéraires sur la construction narrative, sociologique et imagière des problèmes sociaux et sur la façon dont ce journalisme est instrumental dans la révélation de problèmes associés au risque, tels que l'exploitation du travail non qualifié ou la dégradation de l'espace urbain. Nous avons examiné un corpus de textes journalistiques littéraires au travers de méthodes qualitatives, notamment l'analyse du discours et du contenu, pour conclure que le journalisme littéraire et la sociologie utilisent les mêmes méthodologies de collecte de données, interviews, enquêtes, statistiques, dans le but d'exposer les conditions de vie des périphéries socioéconomiques.

Mots-clés: journalisme littéraire, sociologie, problèmes urbains, méthodologies sociologiques.

Resumen El periodismo literario, alojado en el reportaje y en la crónica, intersecta la búsqueda sociológica a nivel metodológico cuando analiza los problemas urbanos. Con el fin de establecer un eje entre el periodismo literario y la sociología, nos enfocamos en la influencia que los primeros periodistas literarios tuvieron en la construcción narrativa, sociológica e imagética de los problemas sociales y como aquel sigue siendo instrumental en la revelación de problemas asociados al riesgo como la explotación de trabajo no-calificado o la degradación del espacio urbano. Examinamos un corpus de textos periodístico-literarios a través de métodos cualitativos, particularmente el análisis de discurso y de contenido, para concluir que el periodismo literario y la sociología acuden a las mismas metodologías de recolección de datos, entrevistas, investigaciones, estadísticas, con el objetivo de exponer las condiciones de vida en las periferias socioeconómicas.

Palabras-clave: periodismo literario, sociología, problemas urbanos, metodologías sociológicas. 


\section{Making a case for the link between literary journalism and sociology}

In the late $19^{\text {th }}$ century something extraordinary of a literary nature happened that would, if not change journalism altogether, at least create a new form of reporting. New Journalism, as this new and vibrant journalism was named contemporaneously by critic Matthew Arnold (1822-1888) in 1887 to refer to the "brash, vivid, personal, reform-minded" journalism of the London-based Pall Mall Gazette (Kerrane in Kerrane and Yagoda, 1998: 17) and that presently is most commonly acknowledged as literary journalism, ${ }^{1}$ was, in fact, a reaction against the massification of news. New Journalism was a form of journalistic response to the endless repetition of the same facts in all newspapers, made cheaper and available to all due to the combined symbiotic effects of the introduction of cellulose paper and the technological advances in the printing industry that occurred throughout the century. Simultaneously, steam lines and telegraph cables shortened distances and allowed for almost instant communication, which also helped disseminate the same news through a smorgasbord variety of printed formats: weeklies, dailies, local, regional, national papers, the morning and evening press, broadsheets and popular magazines. Irrespective of target audiences for which this monumental press was catering, news were not given much thought by journalists and dry factuality was the only norm to follow as far as reporting was concerned. This over objectification of news, that is, "disengaged journalisms that objectify the world as something different or alien from the viewing subject, namely either that of author or reader" (Hartsock, 2000: 17), led to a reaction from within journalism itself that would have undeletable consequences in the way it was perceived and practised. A New Journalism thus emerged and its practitioners, among whom were Charles Dickens, Henry Mayhew and W. T. Stead, the visionary editor of the Pall Mall Gazette, saw themselves as "social reporters" who "aimed at a factual literature of modern industrial life" stemming from their "sense of moral or political urgency: a determination to dramatize the reality of poverty, prostitution, and prejudice" (Kerrane in Kerrane and Yagoda, 1998: 17). The way they were conducting their social reporting was also innovative in the sense that theirs was a journalism that was, not just factual, but literary as it resorted to the same rhetorical devices used by novelists: character composition, scene depiction,

1 Notwithstanding the number of denominations to describe the kind of journalism written with techniques taken from the field of literature, such as scene depiction, dialogue or character construct, and which include "literary nonfiction", "nonfiction reportage", "art-journalism" or "new journalism", "literary journalism" is the most consensual or, at least, widespread one, most especially after the creation in 2006 of the International Association for Literary Journalism Studies (IALJS). In the 1960s, the literary-journalistic style of authors such as Norman Mailer, Truman Capote or Tom Wolfe commonly went under the name New Journalism which was aptly theorised by Wolfe and Johnson in a book titled, precisely, The New Journalism. However, concentrating on the denomination of a journalism characterised by its literariness, Wolfe showed his dislike for the term, adding that "any movement, group, party, program, philosophy or theory that goes under a name with "New" in it is just begging for trouble" (Wolfe and Johnson, 1973: 23). 
dialogue. Besides, this "social reporting" was at a crossroads where journalism, literature and a then new, emerging social science intersected.

The New Journalists ${ }^{2}$ of the $19^{\text {th }}$ century were the precursors of both the new journalists of the $20^{\text {th }}$ century, epitomized and theorized by Tom Wolfe in his The New Journalism (Wolfe and Johnson, 1973) to refer to the non-conventional journalism developed by such names as Norman Mailer or Truman Capote, and our contemporary literary journalists, all a particular breed of journalists who go to the field, carry out legwork and research and basically get so immersed in the topic under scrutiny that become specialists. Their main topic of interest back in the last decades of the $19^{\text {th }}$ century was the urban space, more specifically the poor and derelict neighbourhoods of big cities such as London, Manchester, Chicago, New York, Paris, or even Lisbon. And the social fabric of these areas provided a fertile ground for reporting. More than the founding fathers of literary journalism, New Journalists were also, we argue, early sociologists conducting research on the manifold faces of risk societies: abject poverty and its subsidiary corollaries of insanitation, low life expectancy, disease, infant mortality, pollution, and other major social problems including crime, prostitution and all sorts of vice and human degradation. Concerns about the Other and the inquiry into their lives has ever since been the touchstone of literary journalism as was expressed throughout the $20^{\text {th }}$ century in the works of John Hersey, Michael Herr or Martha Gellhorn, and more recently in the books of investigative reporters/literary journalists the likes of Gabriel Thompson, whose pieces on the lives of Latino illegal immigrants in the United States are a clarion call to the harsh living conditions on the marginalised fringes of affluent societies. Closer to home, this is the journalism of immersion reporting, documentary and literary writing practised by Pedro Coelho in his accounts of life on the socioeconomic peripheries of Portuguese society (Soares, 2011b).

What we purport is to show that literary journalism has, from very early on, not only contributed to expose an incredible array of social problems but has also resorted to the same data gathering instruments that shape sociological research: interviews, participant observation, social surveys, case studies and statistics. Furthermore, literary journalism can be interpreted as akin to mainstream social sciences as it "at times overlaps with the study of folklore and anthropology" (Hartsock, 2000: 27) given its interest in the social body as a whole. Consequently, we aim at demonstrating that, albeit their apparently unrelated natures, literary journalism and sociology are overlapping/intersecting fields when it comes to analysing the sociological field broad and large. Indeed, "it is presently conceived (and there are several contested models on offer) [that] sociology cannot adequately grasp society through its unique methods and concepts" (Ferguson, 2006: 1), a stance implying that the study of the intricacies of social life is far too complex to be left to the social sciences alone. Literary journalism, with its keen interest in "embracing an understanding of the social or cultural Other"

2 For clarity purposes, we write New Journalists when referring to the $19^{\text {th }}$ century and to distinguish them from the new journalists of the $20^{\text {th }}$ century. 
(Hartsock, 2000: 22), may justly add to scientific knowledge of a sociological nature. If this argument can be valid today, it also was in the 19th century, when both sociology and literary journalism were pioneered. Suffice to say that as early literary journalists of the late 19th century were conducting their researches in the poor neighbourhoods of urban centres such as London, Paris or New York and Chicago so too sociology was taking its first steps towards being implemented as a fully-fledged, independent science at university departments in Chicago, Columbia or Paris (Calhoun, 2007: 1). Therefore, we intend to bring an increment to the emerging, and yet sparse, discussion on the existing interdisciplinarity between literary journalism, as a specific genre within journalism, and social sciences, as Gillespie (2012) contends when arguing for "building bridges between literary journalism and alternative ethnographic forms" in an article thus titled.

\section{Reacting to modernity: literary journalism and sociology}

On taking a closer look at the genesis of both literary journalism and sociology, the first thing that calls our attention is that they came about as two contemporary, virtually simultaneous, responses to the overwhelming challenges of modernity: increasing industrialisation and the huge and fast development of great urban centres and their consequences in terms of the potential of risk they brought along. More than providing a starting ground from where to search for common denominators between sociology and literary journalism, the emergence of these two areas within the realms of, respectively, academe and journalism in the $19^{\text {th }}$ century substantiates the fact that a world full of complexities and in permanent transformation posed demanding questions that needed answers to give it consistency and meaning. Indeed, as early theorists explained, journalism, in its broader concept, was a means of understanding the intricacies of the contemporary modern world. In 1931, Clarence Cason, one of the first professors of journalism at a time journalism was making its way into the English departments of American universities and trying to establish itself as an academic field, voiced that: "The magnitude of today's changes, as compared with the extent and rapidity of changes in corresponding periods of the past, renders the present less understandable in terms of the past than ever before" (1931: 374). Cason was therefore calling attention to the fact that, in "dealing with factual aspects of the contemporary scene" (1931:374), journalism was a tool for the general reader to understand a world undergoing transformations at a speed so overwhelming that History could not provide the adequate and immediate answers. If we flash-forward Cason's assumptions regarding journalism and the challenges of understanding society to our present, we also notice that, as far as sociology is concerned, similar worries present themselves to academics. In this regard, Ferguson elucidates that "neither society nor reality falls easily within those schemata of understanding provided by the disciples that now claim a special obligation and competence to define them" (Ferguson, 2006: 2). In other words, modernity does not lend itself to univocal apprehension and a crossroads is possible to find between seemingly disparate fields such as those of literary 
journalism and sociology as will be presently explored. Thus, among the topics under the focus of journalists in the inter-war period of the $20^{\text {th }}$ century, Cason listed social/societal ones such as "the rise of Fascism, Sovietism, and nationalism, [...] prohibition controversies, [...] disarmament controversies, racial conflicts and adjustments, industrialization of the South, prison reform and crime control, farm relief, development of aviation, and administration of justice" (1931: 376), which, taken as a whole, not only reflected early twentieth-century society's concern with the accelerated pace of modernity but also its correlated risks.

At a more specific level, the birth of literary journalism in the $19^{\text {th }}$ century was, as Thomas Connery has noted, "fuelled by a cultural need to know and understand a rapidly changing world" (1990:4) and Phyllis Frus went even further when arguing that New Journalism and the nonfiction novel gained enormous popularity vis à vis other literary genres because they "supposedly answer the need for credibility that the traditional realistic novel can no longer take for granted, given the absurdity of modern life" (1994: xx). Consequently, as far as that early literary journalism was concerned, it came into being as a distinct form of journalism, on the one hand, and, on the other, as yet another attempt at finding meanings for a rapidly changing world that a more canonical and/or conventional journalism had problems providing not withstanding its interest in the newsworthiness of the days' events. Just as early literary journalism, sociology was also concerned with "new inequalities, industrialization, the squalor associated with rapid urbanization, intensified fear of immigrants, crime, and challenges to idealized family life" (Calhoun, 2007: 2-3). Thus, a parallel or overlapping interest can be found as regards the topics scrutinized by the literary or new journalists of the $19^{\text {th }}$ century and early sociologists.

It can further be added that, the notion of risk society, as defined by Ulrich Beck, is also an offspring of the insecurities promoted by modernity: "Risks, as opposed to older dangers, are consequences which relate to the threatening force of modernization and to its globalization of doubt" (1992: 21). Industrialization, clearly a symbol of prosperity and progress, brought with it a gloomier side consubstantiated in problems such as poverty or pollution, which, as Beck perceives, are "risks of modernization" (1992: 21). And it was, precisely, the perils of a society at grips with the finding of symbols and meanings to give it a sense of order and purpose that fell under the attention of the first generations of both literary journalists and sociologists. As industrialism was taking its toll amid vast population segments deprived of the material comforts induced by an increasingly industrial society, literary journalists were looking deep into those social fringes of outcasts, the unemployed and exploited industrial pariahs living in the miserable, polluted and overcrowded neighbourhoods of industrial cities. As Beck also refers "the immiseration of large parts of the population - the 'poverty risk' - kept the nineteenth century holding its breath" (1992: 21-22) and, we might conclude, helped promote a new journalistic genre or New Journalism.

What made this journalism new, the adjective which set it aside from other journalistic forms, was its unashamed resource to techniques more associated with literature than with the Spartan discourse of journalism. The literary embellishment, present in the use of adjectives and adverbs, the creation of scenes, the 
transcript of dialogues and, more boldly, the depiction of characters: their mannerisms, speech particulars and background, would, in time, overshadow the categorization of "New" and replace it in the more modern expression literary journalism, a journalism that is literary in style rather than journalism about literature or literary critique. Still, it was not just literary techniques that distinguished New Journalism and led it to great heights of controversy in the last quarter of the $19^{\text {th }}$ century. ${ }^{3}$

For the first time in journalistic history the journalists' voice was heard in the pieces they wrote. New Journalists, just like their successors of the $20^{\text {th }}$ century, were heretical in the sense that they did not hide their opinions, their interpretation of the facts they were reporting and about which they had researched so profoundly, more often than not by being immersed in the communities they were writing about as was the case with W. T. Stead and his famed series of reports on girl trafficking and the underworld of prostitution in Victorian London. The Maiden Tribute of Modern Babylon (1885) reflected Stead's research incursions into the labyrinth of prostitution and brought to the spotlight an issue that was both controversial and shocking: child abuse and trafficking. The New Journalism in which the series was written caused an outcry of disgust at the scandals being brought to light but, more importantly, it created public awareness to a socially unpleasant situation, immoral in all ways conceivable, and fostered a debate that ultimately led to Parliament passing legislation raising the age for sexual consent. That is, New Journalism was also interested in being an agent for social change and Stead was one of its pioneering crusaders (Jones, 1988: 10).

Also, at a time when the blank spaces of the globe, namely the last remaining terrae incognitae of the African interior, were rapidly disappearing and being explored and charted by the Victorian Burtons, Spekes and Livingstones, new exotic and strange places were being discovered in the urban jungles of the Old Continent and North America. Slums were catapulted to centre stage by the curiosity of proto-literary journalists and sociologists and even by tourists (Rojek and Urry, 1997: 7). Urban geography and the recurrent theme of exploration were the newly-found metaphors with which to explain social divisions and "provided a convenient and graphic means for novelists, journalists, reformers, and social theorists to portray the alarming consequences of the spatial separation and cultural independence of the poor" (Ward, 1976: 323). London and its enigmatic East End became a paradigm of the fin-de-siècle metropolis, the dense urban jungle that William Booth compared to an immense and dangerous forest in the remotest corners of Africa. As he stated while conducting research on the plight of the famished, disenfranchised East Enders:

3 When critic Matthew Arnold coined the expression New Journalism in 1887 he was not defending a "new" form of journalism, he was accusing it of breaking with the canon of conventional journalism by personalising the news report and aiming at social change through the harsh exposure of hidden truths (Kerrane and Yagoda, 1998: 49-50). 
As there is a darkest Africa is there not also a darkest England? [...] The Equatorial Forest traversed by Stanley ${ }^{4}$ resembles that Darkest England of which I have to speak, alike in its vast extent [...], its monotonous darkness, its malaria and its gloom, its dwarfish de-humanized inhabitants, the slavery to which they are subjected, their privations and their misery (n.d. [1890]: 6).

Booth referred to an unknown land within the mighty capital of the colossal British Empire, a place of darkness and human degradation, an inhospitable place to live, a place so far from civilization that, a few years later, American writer and pioneer literary journalist Jack London would have trouble finding even if he had resorted to the experienced guidance of the leading travel agents at Thomas Cook. However:

O Cook, O Thomas Cook \& Son, path-finders and trail-clearers, living sign-posts to all the world, and bestowers of first aid to bewildered travellers - unhesitatingly and instantly, with ease and celerity, could you send me to Darkest Africa or Innermost Thibet, but to the East End of London, barely a stone's throw distant from Ludgate Circus, you know not the way!

"You can't do it, you know", said the human emporium of routes and fares at Cook's Cheapside branch. "It's so - ahem - so unusual."

"Consult the police. [...] We are not accustomed to taking travellers to the East End; we receive no call to take them there, and we know nothing whatsoever about the place at all." (2001 [1903]: 1-2)

This strange, uncharted land was thus the perfect territory to analyse and come in close contact with the Other, the ostracised underbelly living on the social margins of an affluent society, in this case the $19^{\text {th }}$ century equivalent of the world's tentacular superpower, Britain, and also the most industrialised nation on the face of the Earth.

More particularly, New Journalists were venturing into the dark urban jungles of dangerous and poor neighbourhoods, more often than not dressing down as vagrants as was the case with Jack London, so as to have first-hand impressions of that peculiar world. In a century enshrining Science as the privileged means to get to knowledge "observation came to be regarded as the only sure basis of scientific legitimacy" (Rojek and Urry, 1997: 5) and it was, thus, essential to be there where the social fact under analysis was happening just as it was important to bear witness of the newsworthy phenomenon. The sojourns of New Journalists among the poor provided the material that would be digested and published in newspapers such as the immensely popular evening paper Pall Mall Gazette or that would be released to the public in the form of instantly sold-out best-sellers as were Booth's In Darkest England (1890) or London's acclaimed The People of the Abyss (1903). By mingling with the poor, these New Journalists were behaving as the

$4 \quad$ Henry Morton Stanley (1841-1904), British journalist and explorer, famous for his expedition in search of David Livingstone as a correspondent for the New York Herald in 1869. 
participant observer of a reality alien to them. Their main intention was very clear. They dedicated themselves to the study of what they perceived was a strange world: the different social classes, as Charles Booth, no relation to William Booth, categorized them in his detailed Life and Labour of the People in London (1892-1902); the daily lives of the people inhabiting the derelict neighbourhoods, as were described by Henry Mayhew in London Labour and the London Poor (1861-1862) and, in a nutshell, all the problems or risks affecting the thousands and thousands of paupers living in urban areas and that ranged from the high prices of rents, the lack of sanitation leading to disease and mortality, unemployment, alcoholism, vagrancy, prostitution and crime. Furthermore, they were creating a public awareness as to what were social problems. In fact, "recognizing the subjective aspects of social problems allows us to understand how a social condition may be defined as a problem by one segment of society but be completely ignored by another" (Leon-Guerrero, 2005: 6). New Journalists were helping create a notion of social problems not just by exposing to the broader public the living conditions of determined population segments. They were analysing causes and consequences and as a result they were giving shape and visibility to problems that could no longer be loosely interpreted as consequences of the actions of individuals but that had to be inserted and contextualised in the collective social body.

The work of these turn-of-the-century journalists, and the way they perceived their own activity - which was only then starting to be professionalized -, transcended the mere reporting of facts or events. Reporters of the period, as Michael Schudson writes, "saw themselves, in part, as scientists uncovering the [...] facts of industrial life more boldly, more clearly, and more 'realistically' than anyone had done before" (1978: 71). And by doing so they thought of themselves as social scientists and did not consider that their investigative journalism bore much distinction from the work of a more academic social scientist (Weaver and McCombs, 1980: 486). However, the intertwining between journalism and sociology, taken in its whole as a social science, can also be interpreted in a bi-directional way in which not only investigative journalists, strongly rooted in the fin-de-siècle New Journalism, can be likened to social scientists, but the latter also resort to the same tools of the journalist that reports from the field. In a call for arms stating that the social scientist of the late $20^{\text {th }}$ century should recapture the spirit of earlier generations and be more of a committed journalist, Philip Meyer alluded to the methodological import that social scientists gained from journalism practitioners. Thus, social scientists also "relied on observation and interpretation, collecting the observations from public records, from direct participation, and then spinning out the interpretations. [...] The difference was that we journalists put our interpretation in readable English while the social scientists couched theirs in jargon" (cited in Weaver and McCombs, 1980: 488-489). That is, just as much as the New Journalists of the late $19^{\text {th }}$ century were social scientists collecting social data, so were the social scientists carrying out their research as their fellow journalists, there being, consequently, very little distinction between them, which helps us locate an intersection between the spheres of journalism, in this case literary journalism, and sociology. 


\section{The emergence of new/literary journalism: urbanity and methods}

The urban space was one of the first focuses of interest for the New Journalists of the Victorian era and, although John Hartsock categorises literary journalism as being fundamentally a "modal genre, that of narrative" (2000: 13), it is true that by the late $19^{\text {th }}$ century the city and its problems constituted the core of the articles and series brought to light by the investigative New Journalists who were presenting their journalism through narrative. If narrative was these journalists' preferred mode, it is also true that narrative is a fundamental provider of data for the social scientist. In fact, "compositions made after lengthy periods of observation (ethnography) can be narratively organized [...]. Just as interview participants tell stories, investigators construct stories from their data" (Riessman, 2008: 4). Therefore, the use of narrative is a shared instrument for the understanding of data by not only the literary journalist but also the sociologist. But if, as stated, the urban space was of such prominence in the articles published narratively by the New Journalists, we can rightly assume that early literary journalism was a topical genre too, that of urban issues.

The reporting of this pioneering generation of literary journalists on the seemingly endless problems generated by an increasingly urban and industrialized society created an imagological construct of the city as a locus of duplicity where affluence walked alongside unimaginable poverty. Their vision of the city as a place of darkness and human suffering became mainstream and was further given consistency by the novels of Charles Dickens, himself a precursor of New Journalism in his times as a reporter for the Morning Chronicle, and the sombre illustrations of London by George Cruikshank and most-notably those of Gustave Doré. Moreover, this image of the dual metropolis transcended the linguistic boundaries of English and was also appropriated by foreign journalists, namely Portuguese, residing in or travelling to England (Soares, 2011a). London, with its affluent City and its gloomy slums, became the quintessential town of duplicity and the paradigmatic instance of the dangerous urban jungle of all horrors. Venturing into Whitechapel, the ill-famed neighbourhood where Jack the Ripper committed his crimes, Jaime Batalha Reis, Portuguese consul and early literary journalist, for instance, echoed the same images of his contemporary, fellow Anglophone New Journalists. To him, the streets of the East End and their proximity to the financial centre of the City indicated this paradox of an imperial wealthy capital where a great proportion of the population lived in the utmost poverty. Referring to the City and, more specifically to Gracechurch Street, he wrote:

This is the trading centre of the world; it is through the offices on this street [...] that flows [...] all the gold on Earth. But if you continue eastwards, you will get to Aldgate High Street and, not far from there, to Whitechapel, the neighbourhood of the greatest misery, [...] of the most repugnant crimes of all mankind (1988 [1888]: 104). ${ }^{5}$

5 Translation from Portuguese by the author of this article. 
Reis actually spent several days carrying out research in the East End, the results of which were subsequently published in Portuguese and Brazilian newspapers, thus disseminating an image of London as a place of profound social inequalities and risk to a Portuguese-speaking transcontinental audience on both sides of the Atlantic. ${ }^{6}$ As his English-speaking peers, he was resorting to the same data gathering tools among which were direct observation and interviews and he was also completing information by the use of official documents and statistics that he consulted in the British Museum or that he read in the press. His articles are still published today and may be regarded as containers of precise information about Victorian London.

Because New Journalists sought to uncover the inconvenient truths hidden in the great metropolises or urban jungles of the fin-de-siècle, they had to go to the field to collect data. Immersion made them a different kind of journalist. Besides, and although committed to the truthfulness of the facts about which they reported, they were not concerned in presenting to the public an aseptic or larger, objectified and universal Truth. Quite on the contrary, they strove to re-establish a close communication with the reading public that, as they saw it, had been severed by what we might call a more canonical journalism and this meant that they were reporting on facts as they individually interpreted and apprehended them (Yagoda in Kerrane and Yagoda, 1998: 13). That is, New Journalists wrote about what they themselves saw and according to what their own interpretation was (Hollowell, 1977: 22), a positioning regarding the reporting of news that challenged the notion of the journalist as a mere transmitter of events in the most objectified and impartial way possible. The intention underlying this personalization of delivering news was that "by stepping out from the shadows and laying bare his or her prejudices, anxieties, or thought processes the reporter gives us something firmer and truer to hold on as we come to our own conclusions" (Yagoda in Kerrane and Yagoda, 1998: 16). The myth of the neutral voice of the journalist was thus irredeemably shattered and the link connecting the journalist to the public was repaired after a long reign of dry objective impartiality.

In the almost impenetrable urban jungle of the great industrialised cities, New Journalists were going deep into the rough neighbourhoods populated by thousands of paupers. There, they were spending time with their subjects of analysis, scrutinising their reality and reporting on their problems. And they were doing so with their own voices of individuals who happened to be journalists and who also thought of themselves as social scientists. In other words, they were writing their vision and their own interpretation of the facts laid bare before them. As Norman Sims writes when making a comparison between the literary journalists and the journalists latu sensu:

6 The articles that Batalha Reis wrote from England were published in 1888 in the Portuguese periodical O Repórter and from 1893 to 1896 in the Brazilian Gazeta de Notícias. His articles were collectively titled "Revista Inglesa" ("English Review" in a loose literal translation). Inspired by their British contemporary New Journalists, many Portuguese journalists visited London to, like Batalha Reis, also produce their accounts and interpretation of life in that city. Among them are the names of novelist Eça de Queirós, Ramalho Ortigão and Oliveira Martins. 
Literary journalists, as compared with standard journalists, frequently spend more time with their subjects, get to know them, and can crosscheck and evaluate. They triangulate differing stories, sort out participants' memories, make judgment calls, calculate the structure of the story, adopt a point of view, and decipher the symbolism of detail (2007: 16).

Although Sims is here making the apology of literary journalism, it is possible to verify a close similarity between the modus operandi of the literary journalist with that of the sociologist as they both get immersed in field research, in this case direct, and at times participant, observation of a determined community, and then carry out their own particular interpretation of what they saw. In the East End traversed by Charles Booth or Henry Mayhew, William T. Stead, Batalha Reis or Jack London at the turn of the century this is exactly what these proto-literary journalists and early sociologists were developing in terms of data collection and the spinning out of results. Therefore, if no conspicuous difference exists between the New Journalists and sociologists of the late 19th century that is because, on observing and writing about industrial/urban life, they were resorting to similar methodologies.

Life stories were a favourite with New Journalists. On the one hand, they were a means to perfect and popularise a journalistic technique that was only then giving its first steps and that today is regarded as a sine qua non requisite of journalism: the interview. ${ }^{7}$ On the other, they brought the human interest factor that propelled the selling of newspapers. Life stories are narrative in mode and therefore aptly suited for a modal genre such as literary journalism. Similarly, social scientists often delve into life stories, narrative thus providing the vehicle for research in such fields as social history, anthropology, psychology and sociology. As Riessman argues in this respect, "here, personal narrative encompasses long sessions of talk - extended accounts of lives in context that develop over the course of single or multiple research interviews or therapeutic conversations" (2008: 6). Just like social scientists today carry out single or multiple research interviews to get to the "extended accounts of lives in context", so too early literary journalists were using this same research method.

London Labour and the London Poor is a clear instance of the use of life stories with the purpose of analysing London's "street people" and their occupations. Henry Mayhew interviewed hundreds of subjects to produce his study and the compilation and edition of such personal stories provided an illustration of the living conditions of the poor in London. As Kevin Kerrane stated, as regards the impossibility of dissociating Henry Mayhew the sociologist from Henry Mayhew the New Journalist: "Mayhew saw his work as a venture in practical social science [...] but his style remained more literary than sociological" (in Kerrane and Yagoda, 1998: 34). That is, he was a distinct kind of journalist because he was a literary journalist all the while being a researcher in social science. He included entire

7 The interview was actually one of the innovations introduced by New Journalism and W. T. Stead was a promoter of the technique (Brown, 1985: 160-164). 
transcripts of his subjects' interviews and fleshed them up with his description of them and of the environment in which he had interviewed them. And he also elucidated his reading public as to his method for putting his interviewees at ease and therefore extract information from them. Talking about a young eight-year girl who sold watercress, he stated:

I did not know how to talk with her. At first I treated her as a child, speaking on childish subjects; so that I might, by being familiar with her, remove all shyness, and get her to narrate her life freely. I asked her about her toys and her games with her companions, but the look of amazement that answered me soon put an end to any attempt at fun on my part (In Kerrane and Yagoda, 1998: 35).

Clearly, Mayhew was not behaving as a conventional, say impartial, journalist. Writing in the first-person, he exposed the man behind his journalistic self. He was the reporter willing to share his feelings with the public and not afraid to say how difficult it was to get information from the subjects he was scrutinising. But similarly he was also the social scientist trying to obtain faithful information on child labour and hence his effort in obtaining the cooperation from his interviewees. The life story of the little watercress girl, filled with all its predicaments, together with so many other life stories he gathered, would thus prove an insightful chapter on the harsh lives of thousands of children deprived of childhood on account of extreme poverty in the worst neighbourhoods of London. His work is regarded as a document of historical importance to a bygone era, a time-window that allows contemporary social scientists to analyse reality as it was like in the dangerous, dimly-lit streets of the Victorian East End.

Because the interview was such a disseminated means that New Journalists used for the gathering of information, survey research can also be found in the reports they were bringing to light on the plight of the urban poor. Truly, these were incipient surveys that lacked a scientific canon as regarding the specific methodologies of questionnaire writing and delivery. But, nonetheless, conducting thousands of interviews meant that some amount of information could be compiled numerically. Statistics were indeed much used in the early days of New Journalism. W. T. Stead, Charles Booth and William Booth, to name but a few, resorted quite often to statistical information that they also extracted from the interviews they conducted. And this was a way New Journalists had of stamping their texts with an imprint of credibility and accuracy while exposing to their bewildered audiences the countless iniquities of life below the poverty line. In his In Darkest England and the Way Out, William Booth analysed prostitution and its causes and social consequences. In order to do so he used life stories and interviews made to one hundred girls, young prostitutes "crushed beneath the millstone of social excommunication" (n.d. [1890]: 45). As seen on table 1, after compiling the information extracted from the interviews, he got to the "CAUSE OF FALL", ${ }^{8}$ his terminology for the direct reasons that lead young girls to prostitution:

$8 \quad$ Capital letters by William Booth. 
Table 1

Causes for prostitution among young girls (Booth, n.d. [1890]: 46).

\begin{tabular}{lr}
\hline Drink & 14 \\
Seduction & 33 \\
Wilful choice & 24 \\
Bad company & 27 \\
Poverty & 2 \\
Total & 100 \\
\hline
\end{tabular}

Booth was thus able to verify and explain to his readers what made girls from impoverished backgrounds sink into the abyss of prostitution: alcoholism, the bad influence of third parties, their own choice and their socioeconomic status. He was therefore defining, through objective data, a social problem and, more importantly, by bringing his study to light, he was "taking a private trouble and transforming it into a public issue" (Leon-Guerrero, 2005: 7). That is, prostitution could not be blamed or attributed to individuals alone, it was an issue stemming from a set of conditions that made it a societal problem. Booth further highlighted that out of these one hundred girls, twenty-three had been in prison and he then went on to analyse the implications that prostitution had in the health of these girls and what other consequences derived from the business, which included heavy drinking and the cruel treatment at the hands of "their bullies" (n.d. [1890]: 47). By resorting to this kind of factual information, he could corroborate the conclusions he came to, not only those pertaining prostitution but also those regarding other social risks such as unemployment, homelessness, alcoholism, crime. And he was, therefore, equipped to draw a clear picture of the society inhabiting the strange geographic periphery he called "Darkest England". W. Ross Winterwod elucidates that New Journalism, the literature of fact, the non-fiction novel, literary journalism or whatever we choose to call it, wants to achieve "documentary credibility - the grounding in verifiable fact" (1990: 60) and survey research with its concomitant statistical information endows literary journalism with the truthfulness it aims at and further likens its methods to those used by the sociologist.

Immersion reporting, which can be compared to participant observation in the cases when the journalist becomes one of the members of the group he want to study, was also a characteristic that distinguished the New Journalism of the fin-de-siècle and that, in this day and age, still differentiates literary journalism from a more conventional journalism all the while paying "attention to ordinary lives, and the special qualities of a writer's connection to the subjects" (Sims, 2007: 12). Jack London is probably the most renowned turn of the century case of a reporter deeply immersed in a community that he wanted to study and about which he wanted to write.

In 1902, he arrived in London determined to spend some weeks as a vagrant in the East End in order to conduct research on the Other, the ostracised huddled masses like some abject human refuse of an industrialised superpower. He bought rags from a dealer, took off his shoes, sewed a gold sovereign to his tattered clothes in case an emergency arose and down he went to the East End. Blending with the subjects of his study was a means to get a better understanding of their lives and problems, a way to 
connect to the subjects he was analysing as Sims referred. And as London confirmed:

No sooner was I out on the streets than I was impressed by the difference in status effected by my clothes. [...] In the twinkling of an eye, so to say, I had become one of them. My frayed and out-at-elbows jacket was the badge and advertisement of my class, which was their class. [...] For the first time I met the English lower classes face to face, and knew them for what they were (2001 [1903]: 6-7).

This last sentence is of particular relevance. By dressing down, London could know the East End as it really was, without the interference of social distinctions. It gave him mobility and freedom of observation. And by being unaware of whom he was and what he was doing, people behaved and talked to him in the most natural manner and this gave him the opportunity to be "an investigator, a social student, seeking to find out how the other half lived" (London, 2001 [1903]: 43). London congregated in himself, and was much self-conscious of, the double role of being a journalist on an assignment and a social scientist carrying out research. The result was a book, The People of the Abyss, that reads like a report on the living conditions of the poor and that presents London's own conclusions based on the examples he gives, the interviews he transcribes, the statistics he shows, the life stories he tells, all of which denouncing a society of multiple social hazards. As he concludes:

Civilization has increased man's producing power. Five men can produce bread for a thousand. [...] Yet it has been shown throughout the pages of this book that English folk by the millions do not receive enough food, clothes and boots. [...] Civilization has made possible all manner of creature comforts and heart's delights. In these the average Englishman does not participate. If he shall be forever unable to participate, then Civilization falls (2001 [1903]: 169).

London's opinion of a divided society almost on the verge of civilizational collapse is not concomitant with a more mainstream view of journalism in which the journalist simply eliminates all possibility for opinionated discourse. London went to the East End to live it, to gather first-hand information and be able to portray it to his readers. His journalism was new. It is literary journalism standing as "a humanistic approach to culture as compared to the [...] abstract, or indirect approach taken by much standard journalism" (Sims, 2007: 12). But his journalism was also an endeavour in social science as was the journalism of his contemporary fellows New Journalists who were studying modern societies, not just in the Londoner East End but also in other great urban centres, and bringing to light the manifold socioeconomic discrepancies of the modern era.

\section{Conclusions: literary journalism and contemporary society}

As late as 1973, Tom Wolfe was still using the expression New Journalism to describe the particular journalism "that fell outside the category of hard news" (1973:5) and 
that was likened to that of the iconoclast journalists of the fin-de-siècle. For lack of a better categorization, this New Journalism (that was already mature and therefore not exactly new by the 1960s and 1970s) was considered a "parajournalism" (Wolfe, 1973: 24) because its writing techniques were imported from the realm of literature and its methods for the gathering of information were alien to mainstream journalism. Still, the aims of researching a subject thoroughly, as exemplified by Capote's five years of interviews and research to write his best-selling In Cold Blood (1966) about the brutal murder of a family of farmers in Kansas, were as present in the twentieth-century works of new journalists, by now starting to be named literary journalists, as they had been a century before. Although the urban setting had been a favourite with the first generations of literary journalists, the $20^{\text {th }}$ century witnessed an increased interest in other subjects from which to engage in experiments in immersion reporting of a sociological value-added nature which had social problems and the Other as an underlying common denominator. Contemporaneously, Michael Burawoy, when arguing for the extended case method in ethnographic research, suggests that "reflexive science sets out from a dialogue between us and them, between social scientists and the people we study" (1998: 7) further adding that "living in the time and space of those one studies makes it difficult to fit the world into a predefined template" (1998: 11). This concern with the Other and bridging its world to that of the researcher was already present as a worry in the literary journalists of the $19^{\text {th }}$ century and early sociologists to an extent that Burawoy's observations can be read with hindsight into the world of the first generations of literary journalists. War reports are another clear instance of both immersion into the world of the Other and bridging its experience with the universe of the Us as demonstrated by the features broadcast in one of BBC's most popular radio series "From Our Own Correspondent" in which reporters cover a profusion of issues, more often than not associated with war-stricken places and living conditions in undemocratic regimes around the world. Indeed, these features are far from fitting in the category of mainstream journalism and correspondents have the opportunity "to sit down and write at some length, perhaps 800-words, a five-minute broadcast, about the story, the characters in it and the surroundings in which it is developing" (Grant, 1996: ix), an in-depth contextualisation and research often lacking in conventional news reporting and akin to the work developed by social researchers.

Urbanity and its problems have, however, remained popular with literary journalists throughout the $20^{\text {th }}$ century and into the new millennium as shown by the countless editions of George Orwell's Down and Out in Paris and London (1933), about his experience as a vagrant and menial worker in the Parisian and Londoner bas-fonds. Treading in the footsteps of the pioneering generations of literary journalists, Gabriel Thompson's inquiries into the lives of undocumented immigrants in New York offer a possibility to analyse how interconnected literary journalism and sociological research are contemporaneously. Just like London or Orwell, whom he actually acknowledges as an inspirational source, Thompson chose immersion reporting for its "unique ability to explore fascinating and sometimes brutal worlds that are usually kept out of sight" (2010: xiv). Finding low-skilled, 
low-paid jobs in shops and restaurants was a means to mingle with Latino illegal labourers and thus gather substantial information regarding the underworld of the parallel labour market in a big city that was then written narratively. Participant observation, interviews, the transcription of life stories, the resource to official statistics were all tools for data gathering that Thompson used to produce both There's No José Here (2007) and Working in the Shadows (2010) his meticulous accounts of the lives of illegal immigrants of Latino origin in the United States. Little, in fact, separates Thompson's literary journalism of the new millennium from either the modus operandi of his literary journalism ancestors or the working methodologies of social scientists, their gathering of life stories, their periods of observation/immersion and interviewing.

When looking at the similarities between the reporting of literary journalists and the scientific labour of sociologists, the comparison is not a mean one, it raises the discussion as to what extent does one preclude the other or, if, as we have tried to demonstrate, one and the other can complement each other to present society at large and the interested reading public in particular the idiosyncrasies of modern societies. Ultimately, establishing a bridge between literary journalism and sociology implies that:

The significant overlaps in the roles, perspectives, and interests of journalists and social scientists argue for increased communication and cooperation between the two. Both groups are interested in observing the external world, and [...] both disciplines are trying to describe reality, to answer the question, "What is going on around here?" [...] Both share an empirical base - a concern for observable evidence to support conclusions (Weaver and McCombs, 1980: 491).

In the late $19^{\text {th }}$ century, the emergence of what Matthew Arnold acrimoniously called New Journalism, characterizing it from his conservative perspective as "featherbrained" (Kerrane in Kerrane and Yagoda, 1998: 17), walked hand-in-hand with the sociological study of impoverished social fringes in great urban centres. Pioneering literary journalists gave relevance to the risks of urbanity which meant pointing the finger at the degrading living conditions under which millions of people lived and portraying life in the slums of industrial towns as one of misery, crime and vice in all their most horrid faces. Their depiction of urban life was based on thorough research that involved a number of methods that are also used by social scientists. A clear distinction between literary journalism and sociology is thus blurred inasmuch as the topics analysed and the methods used to produce information are concerned. These blurred lines are still the more visible today with the emergence of autoethnography and public ethnography, "both of which aim to be more personal, narrative, and publicly engaged types of research and have striking similarities to literary journalism in both practice and product" (Gillespie, 2012: 71).

We are not stating point-blank that literary journalism, or its nineteenth-century equivalent New Journalism, are straightforward sociology but both intersect at an interstice that contemplates methods and an acute interest in the social body that calls for our attention. New Journalists, in the end, were proto-social scientists uncovering the problems lurking in a modern, industrialised and urban society marked by its 
duplicity and, as journalists of a different kind, they were the mouthpiece denouncing the perils of urban life. Their heirs, modern literary journalists, continue the tradition of investigating risk in our contemporary world. And when and if further research on the intersecting boundaries between literary journalism and sociology is carried out, the conclusion to be had may probably be that both are indeed Sociology, with a capital letter, undertaken differently by respectively long-form investigative journalists and licensed professionals in an academic field within the Social Sciences. However, one should not abruptly jump to the conclusion that narratology, as applied to the fields of both literary journalism and the social sciences in their use of, for instance, the life story, is enough to convey scientific merits and unchallengeable results to narrative emanating from those two fields. In an age when narrative is so pervasive and found intertwined with political discourse or a staple in social media "specificity has been lost with popularization" (Riessman, 2008: 5). A caveat must therefore insist that narrative should be approached with care and that, albeit intersecting, literary journalism and social sciences find their places in different niches of human knowledge. That such intersection exists is, however, an increment to the study of risk, urbanity or social problems from a transdisciplinary perspective, literary journalism providing, for example, the corpus for sociological research.

\section{References}

Beck, Ulrich (1992), Risk Society. Towards a New Modernity, London and New Delhi, Sage Publications.

Booth, William (n.d. [1890]), In Darkest England and the Way Out, McLean, VA, Indy Publish. Brown, Lucy (1985), Victorian News and Newspapers, Oxford, Clarendon Press.

Burawoy, Michael (1998), “The extended case method”, Sociological Theory, 16 (1), pp. 4-33.

Calhoun, Craig (2007), "Sociology in America: an introduction", in Craig Calhoun (Ed.), Sociology in America: A History, Chicago, The University of Chicago Press, pp. 1-38.

Cason, Clarence E. (1931), "Journalism as social science”, Social Forces, 9 (3), pp. 370-377.

Connery, Thomas (1990), "A third way to tell the story: American literary journalism at the turn of the century", in Norman Sims (Ed.), Literary Journalism in the Twentieth Century, New York, Oxford University Press, pp. 3-20.

Ferguson, Harvie (2006), Phenomenological Sociology. Experience and Insight in Modern Society, London, Sage Publications.

Frus, Phyllis (1994), The Politics and Poetics of Literary Journalism. The Timely and the Timeless, Cambridge and New York, Cambridge University Press.

Gillespie, Bruce (2012), “Building bridges between literary journalism and alternative ethnographic forms: opportunities and challenges", Literary Journalism Studies, 4 (2), pp. 67-80.

Grant, Tony (Ed.) (1996), More from Our Own Correspondent, London, Profile Books.

Hartsock, John C. (2000), A History of American Literary Journalism. The Emergence of a Modern Narrative Form, Amherst, NY, University of Massachusetts Press.

Hollowell, John (1977), Fact and Fiction. The New Journalism and the Nonfiction Novel, Chapel Hill, NC, University of North Carolina Press. 
Jones, Victor P. (1988), Saint or Sensationalist? The Story of W. T. Stead, 1849-1912, East Wittering, Gooday Publishers.

Kerrane, Kevin, and Ben Yagoda (Eds.) (1998), The Art of Fact. A Historical Anthology of Literary Journalism, New York, Touchstone.

Leon-Guerrero, Anna (2005), Social Problems. Community, Policy, and Social Action, Thousand Oaks, CA, Sage Publications.

London, Jack (2001 [1903]), The People of the Abyss, London and Sterling, VA, Pluto Press.

Reis, Jaime Batalha (1988 [1888]), Revista Inglesa. Crónicas, Lisbon, Publicações D. Quixote / Biblioteca Nacional.

Riessman, Catherine Kohler (2008), Narrative Methods for the Human Sciences, Thousand Oaks, Sage Publications.

Rojek, Chris, and John Urry (Eds.) (1997), Touring Cultures. Transformations of Travel and Theory, London and New York, Routledge.

Schudson, Michael (1978), Discovering the News. A Social History of American Newspapers, New York, Basic Books.

Sims, Norman (2007), True Stories. A Century of Literary Journalism, Evanston, IL, Northwestern University Press.

Soares, Isabel (2011a), “Literary journalism's magnetic pull: Britain's 'New' Journalism and the Portuguese at the fin-de-siècle", in John S. Bak and Bill Reynolds (Eds.), Literary Journalism across the Globe: Journalistic Traditions and Transnational Influences, Amherst and Boston, University of Massachusetts Press, pp. 118-133.

Soares, Isabel (2011b), “'The Island of Loneliness'? Literary journalism from the Azorean periphery", in David Hutchinson and Hugh O'Donnell (Eds.), Centres and Peripheries. Metropolitan and Non-Metropolitan Journalism in the $21^{\text {st }}$ Century, Newcastle upon Tyne, Cambridge Scholars, pp. 215-225.

Thompson, Gabriel (2010), Working in the Shadows. A Year of Doing the Jobs [Most] Americans Won't Do, New York, Nation Books.

Ward, David (1976), "The Victorian slum: An enduring myth?", Annals of the Association of American Geographers, 66, pp. 323-336.

Weaver, David H., and M. E. McCombs (1980), “Journalism and social science: A new relationship?", The Public Opinion Quarterly, 44, pp. 477-494.

Winterwod, W. Ross (1990), The Rhetoric of the "Other" Literature, Carbondale and Edwardsville, IL, Southern Illinois University Press.

Wolfe, Tom, and E. W. Johnson (Eds.) (1973), The New Journalism. With an Anthology, New York and London, Harper \& Row.

Isabel Soares (corresponding author). Assistant Professor, Instituto Superior de Ciências Sociais e Políticas, Universidade de Lisboa, Lisboa, Portugal.

E-mail: isoares@iscsp.ulisboa.pt

Receção: 28 de janeiro de 2014 Aprovação: 04 de outubro de 2016 